\title{
The Application of Multigamma Radiation as a Physical Mutagen for Breeding of Local Soybean
}

\author{
Bartholomeus Pasangka ${ }^{1} \&$ Refly $^{2}$ \\ ${ }^{1}$ Department of Physics Faculty of Science and Technology, Nusa Cendana University, Kupang, Indonesia \\ ${ }^{2}$ Department of Biology Faculty of Science and Technology, Nusa Cendana University, Kupang, Indonesia \\ Correspondence: Bartholomeus Pasangka, Department of Physics Faculty of Science and Technology, Nusa \\ Cendana University, Kupang, Indonesia. Tel: 62-380-881-597. E-mail: bpasangka15@gmail.com
}

\author{
Received: February 18, 2013 Accepted: April 7, 2013 Online Published: May 15, 2013 \\ doi:10.5539/jas.v5n6p201 URL: http://dx.doi.org/10.5539/jas.v5n6p201
}

\begin{abstract}
The general effect of multigamma radiation causes mutation on the all species of plant. The largest effect of multigamma radiation was occurred on genetics factor and chromosome, specific on structure and composition of chromosome and DNA. This case can be used for breeding of several importent plants in the world. The objective of this research is the breeding of local soybean (Glycine max L) from Bajawa Flores NTT Indoneisa with aplicaton of multigamma radiation to obtain the primer seed of local soybean with high production and tolerant to dry condition. There were ten (10) varieties of primer seed or superior seed was obtained from mutation by multigamma radiation treatment. The production was revolved between 3.78 tons/ha up to 4.92 tons $/$ ha, with mean production 4.41 tons/ha. The mean production of initial soybean (control) is 2.54 tons/ha, just as the production was increased significantly by 42.40 percent.
\end{abstract}

Keywords: multigamma, radiation, breeding, mutation, soybean

\section{Introduction}

Mutation is a changing process on genetics matter of an organism, which spontaneously occurred (called spontaneous mutation) and random, and also through induce mutation (Soedjono, 2003). Those process produce genetics variation as the basic of plant selection (natural or breeding), in order that, the breeder is easy to select of genotive apropriate to purpose of breeding (Gepts \& Hancock, 2006; Carsono, 2008). Induce mutation on the plants can be done to reproduction organ of plant like as: seed, cutting stalk, pollen, rhizome, etc. On general, physical mutagen is radioactive source which high energy that produced by nuclear reaction.

There are two categories about theory of radiation effect (Hollaender, 2002): 1) Target theory or direct action theory. The biologists qualitatively and quantitatively investigate and explain the cell multiplication and mutation on the organism, and around vital structure or molecular structure. Biologists begin their investigation on outher morphology effect of organism, continuously to sensitive spot and vital structure (Handayani, 2006). Continuously research on citology and genetics obtained the changing in molecular structure; 2) Indirect action theory. This theory comes from chemicalists whose begin their investigation about radiation effect on act aspect of molecular and continued to macromolecular which cell composing, like as DNA, RNA, protein, etc for easy explaining of organism mutation. Another effects of nuclear radiation:

\subsection{Radiation Effect Ionizes Nucleic-Acid and Nucleo-Protein.}

Nucleic-acid and nucleo-protein are important component in chromosome which support characterisric of generation (Hollaender, 2002). Ionization energy disturbs of cell fission and mutation that causes chromosome aberation. Multigamma radiation produces depolarization and viscosity descent on thymonucleic acid (TNA), impedes syntesis of deoxyribo nucleic acid (DNA).

\subsection{Radiation Effect to Protein}

Multigamma radiation leads the changing of struture and composition of chromosome and DNA on several species of plant. This process leads several forms of mutation on the plant generation which characteristics differenced to initial plant. The small doses of radiation as big as $10 \mathrm{mSv}$ up to $100 \mathrm{mSv}$ cause $1 \%$ speed of DNA naturally broken. The several approaches of physics and biology have been done for illustrating of doses limit and speed of 
low doses. According to microdosimetry aspect, low doses is smaller than $1 \mathrm{mGy}$, radiobiology: low doses is 20 mGy, epidemiology: low doses 200 mGy (UNCEAR, 2005).

\subsection{Radiation Effect on DNA}

DNA structure formed of double helicks which composed from bundle between phosphate group and dioxiribo sugar that form of strand DNA, and bundle between nitrogen bases which connect to two strands DNA. A large parts broken of DNA are broken on bases, bases lost, the bundle between bases has broken, and the bundle of sugar and phosphate has broken, in order that, occurred broken on one strand is called single strand break (ss $b$ ). This damage can be quickly reconstructed without mistake by enzymatic repairs process with using strand DNA that is not break as mold. Cell can do the contruction process to the broken of DNA in a few hours, but can be not perfect, mainly to the broken of DNA is called double strends breaks $(d s b)$ (Brenner, 2006). The reconstruction process with mistaking causes mutaion of abnormality genetics and chromosom. Figure 1, illustrates the broken on DNA as consequnce of radiation.

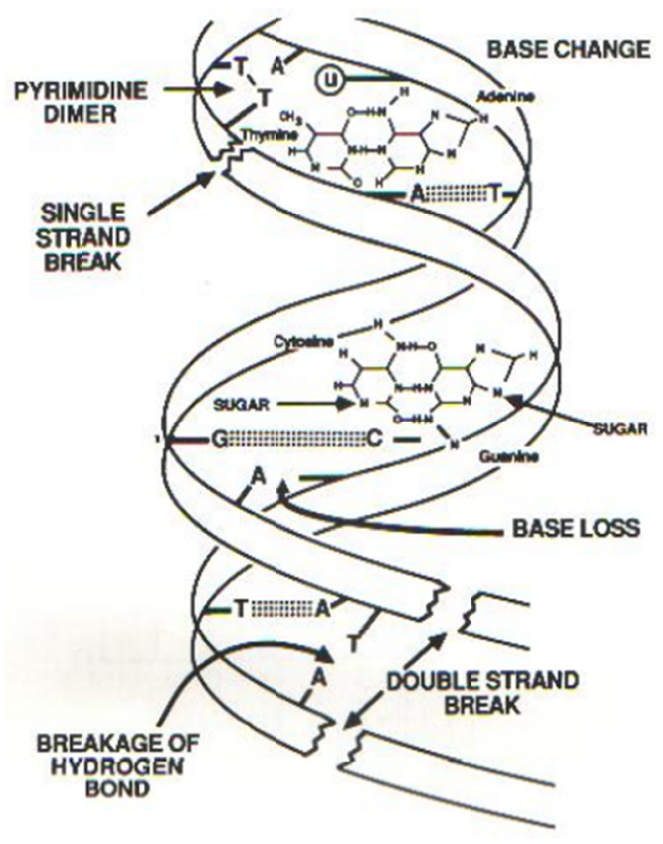

Figure 1. The broken of DNA as consequnce of radiation (Brenner, 2006)

\subsection{Radiation Effect on Chromosome}

Multgamma radaition causes changing of chromosome structure. Normally, chromosome comprises of upper-arm and fore-arm connected by a centromer. Multigamma radiation causes the forming of: 1) assentric fragment (formed of chromosome fragment without centromer); 2) disentric chromosome (chromosome has two centromers); 3) ring chromosome; 4) translocation (removal of genetic matter betwen chromosome arm) (UNCEAR, 2005).

Mutation on the plant is spontaneously changes of genetic matters in cells caused by (IAEA, 2008): 1) rearrangement occurred on chromosome structure; 2) changing in genetics; 3) segments duplication of chromosome loss. Physical mutagen is mutagen which uses ionizing radiation, like as: alpha ray, beta ray, gamma/multigamma ray, X-ray, neutron, proton, acceletaor particle, etc. Radiation technique has several superiorities among others: 1) radiation technique is easy to do and practical; 2) the change of genotive a few only, but causes much changes of characteristics on generation species; 3) the generation species obtain in the short time.

Dosage standard of gamma/multigamma radiation is used on breeding of plants (IAEA, 2003, 2004, 2006): 1). Mutation on plants: 100 rads up to 3,000 rads; 2). Mutation in seeds plant: 1,000 rads up to 4,000 rads; 3.) Growth stimulation of seeds plant: 250 rads up to 1,000 rads; 4). Growth obstruction on root: 5,000 up to 10,000 rads (NNEA, 2005). 
This research focused on development of local soybean from Bajawa Flores with using multigamma radiation technique. This method obtain enable several variations of superior generation variety, in order that is easy to select superior variety. The general characteristics of superior seed of soybean variety are: 1) high production; 2) the age of plant is shorter; 3) tolerant to germ specially viruses (Radiyanto \& dkk, 2011); 4) tolerant to plant disease like as agromyza, phaedonia inclusa, lamprosema litura, riptortus linearis, etiella zinkkenella, and nezara viridula (Sunarto, 2003; DP2TP, 2006); 5) tolerant to abiotic conditions like as dry condition (Hartati, 2000); 6) the quality of seed increase (content of protein and fat) (Irwan, 2006; NNEA, 2008). The soybean is the first impotent logumes in Indonesia, which high content of nutrient as a protein sources of concerning plants and low cholesterol, and also the price is reached by the all societies. The soybean requirements on every year in National scale always increase (Amaliyah, 2009). In 2004, the production of soybean in the country only $1,878,898$ tons, while requirement of soybean in National scale on this time achieve 2,955,000 tons (Indrawan, 2009). The mean production of soybean in the world this time achieve 1.9 tons per hectare, while the mean production on National scale achieve 1.2 tons per hectare Amaliyah (2009). The last time, soybean production decrease. It's consequence is the goverment to import the soybean as many as 300 thousand tons every year (Arsyad \& Syam, 2004).

As the fasting 2018, estimetad that request projection of soybean achieve 6.11 million tons, while in 2003, the production of soybean 672,000 tons only, in 1992, the production of soybean achieve 1.87 million tons (Hilman et al., 2004; Atman, 2006). The commodity production of soybean per hectare in Indonesia is not achieve maximum product. That is influenced by soil factor which damaged and poor of micro-elements, growing hormone, dry conditions, germ, climate, and the using of superior seed (DP2TP, 2006). The soybean as the part of food self-sufficient in Indonesia is a commodity which still low production in the farmer level (Indrawan, 2009).

These research aimed: to develop local soybean variety from Bajawa Flores through breeding with aplication of multigamma radiation method and carefully selection to obtain superior seed with high production, and tolerant to dry condition.

\subsection{Several Researches have been Done by Researcher}

On 2009, successed to develop local sweet yellow corn and sweet white corn, which tolerant to dry conditions, high calsium and salt. The increase of mean production is $46.20 \%$ (from 3-7 tons/ha go up to $11-15$ tons/ha) for sweet yellow corn and 40.00\% (from 3-6 tons/ha go up to 9-10 tons/ha) for sweet white corn (Pasangka and Jaelani, 2010).

On 2010, researcher successed to develop erect local penaut and creep local peanut from East Sumba with using multigamma radiation. The increase of mean production $43.86 \%$ for creep local peanut and $42.22 \%$ for erect local peanut, or mean production 5.7 tons/ha (from 3.2 tons/ha up to 5.7 tons/ha) for creep local peanut, production potential 5.9 tons/ha, and 4.5 tons/ha (from 2.6 tons/ha- 4.5 tons/ha) for erect local peanut, production potential 4.7 tons/ha (Pasangka and Jaelani, 2011).

On 2011, continuous research, of perifying obtained production to be revolved between 4.75 tons/ha up to 6.84 tons/ha for creep local peanut, and between 3.95 tons/ha up to 5.45 tons/ha for erect local peanut (Pasangka and Jaelani, 2011).

\section{Material Studied}

The main instruments used in this research consist of: 1) Multigamma radiation source; 2) counter of radiation doses; 3) protein analyzer; 4) tractor; 5) digital balance; 6) other equipments. The sample for breeding is local soybean from Bajawa, Flores Island Indonesia. There are two groups: control sample and treatment sample.

\section{Area Description}

The research area located in Kupang West Timor Island Indonesia, at five areas (the name of locations are: Fukdale, Oesao, Baumata, Tabenu, and Bolok). The 5th location is different condition like as high salt and calcium, dry condition, soil struture, and illumination.

\section{Methods}

The methods of research comprise of: obsrvation/ surveying, sampling, radiation, selection, comparison, and interpretation. Collecting and data analysis are done with observation, measurement, protein analysis on initial soybean and also on generation soybean (mutan). Quality control is done to compare between analysis results of control (initial soybean) and analysis results of generations soybean (mutan). The superiority of this methods is obtained superior seed in short time and many variations of superior seed varieties (is easy to select generation variety or the best superior seed). The development of local soybean in these research, uses multigamma radiation 
method. Multigamma radiation method lead of gecetic effect like as the changes of structure and composition of chromosome, and molecule of deoxiribo nucleat acid (DNA) on several species of food plant.

\subsection{Procedures of Research}

The simple procedures of this research comprise of : 1) to determine research location and choose sample of local soybean; 2) to design example garden; 3 ) to irradiate samples of soybean seeds; 4) to plant sample of soybean in the area has been prepared; 5) watering if it is necessary; 6) weeding and cultivating; 7) observation to tenacity of germ, growth in dry area, high calsium and salt, and physical characteristics which is needed as a standard comparison, and also select plants. On the resemble harvest, is done selection, measurement of high plant, in time after harvest is measured of mass for a group of 1,000 soybean seeds; 8) to analize protein (service analysis model); 9) drying and selection; 10) For quality control is done comparison between analysis results of control (initial local soybean) and analysis results of generation varieties (mutan);11) The last procedure is to put insecticide sufficient to superior seeds of soybean and storage for continuously development. The first selection of soybean plant is done since the age of plant is one month, the second selection since the age of plant two months, $M_{n}$ selection since near to harvest, and the third selection after harvest.

\subsection{Observes and Measures}

The amount of physical characteristics of soybean (Control sample and mutan) during growth and after harvest was observed and measured like as adaptation, tenacy of germ, grow time, age to be flowered, high of plant, and weight per 1,000 seeds, protein content, potential production, and mean production.

\subsection{Research Design}

The Soybean sampling was chosen from local soybean. There were two categories of sampling, i.e control sampling (initial soybean) and treatment sampling. The treatment sampling (seeds of soybean) was irradiated by multigamma sources on radiation dosage 3.500 rads. The both sampling was planted in the same time and location. During growth was done observation and three selections (First, second, and third), and after harvest was done one selection. Figure 1, show detail of research design. The first selection of soybean plant was done since the age of plant was one month, the second selection since the age of plant was two months, $M_{n}$ selection since near to harvest, and the third selection after harvest.

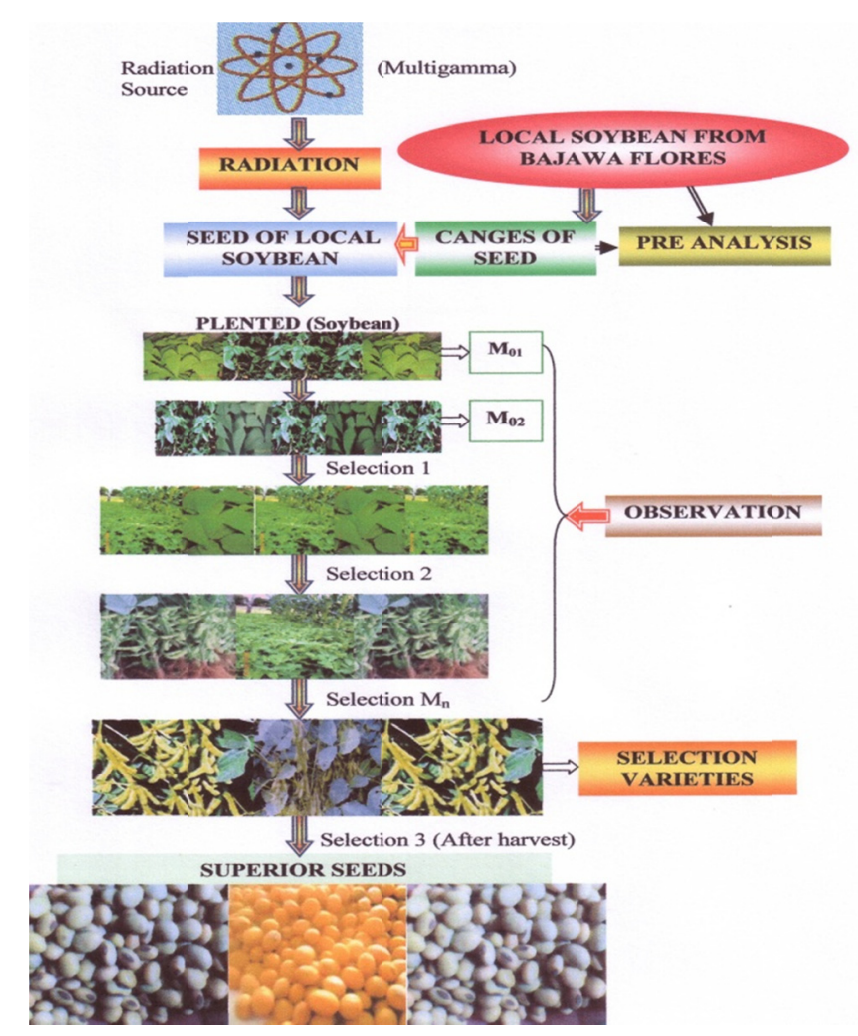

Figure 1. Research design 


\subsection{Statistical and Data Analysis}

Statistical formula was needed to calculated grow percentage and percentage of increasing of mean production. For testing of grow percentage, we choose five sample groups at random on control and treatment sample. The number of test sample is 100 seeds on every group. The number of seeds sample was not grown to be observed. The grow percentage was calculated by equation:

$$
G P=\left(\frac{T_{S G}-N_{S N}}{T_{S G}}\right) \times 100 \%
$$

Where: $G P$ is grow percentage (\%), $T_{S G}$ is total number of seeds to be planted (prepared sample), $N_{S N}$ is the number of seeds was not grown. The percentage of increasing of mean production was calculated by formula:

$$
P_{i}=\left(\frac{M_{P}-M_{C}}{M_{P}}\right) \times 100 \%
$$

Where: $P_{i}$ is percentage of increasing of mean production, $M_{P}$ is mean production of mutan, and $M_{C}$ is mean production of control. Mean production was calculated by equation:

$$
M_{P}=\frac{P_{1}+P_{2}+P_{3}+P_{4}+P_{5}}{5}
$$

Where: $P_{i}, P_{2}, P_{3}, P_{4}, P_{5}$ are production at 5 locations.

\subsection{Calculations}

Based on equation (1), grow percentage of seeds on control sample and mutan can be determined. Grow percentage of control sample $G P=\left(\frac{T_{S G}-N_{S N}}{T_{S G}}\right) \times 100 \%=\left(\frac{100-18}{100}\right) \times 100 \%=82 \%$.

Grow percentage of mutan ${ }_{G P}=\left(\frac{T_{S G}-N_{S N}}{T_{S G}}\right) \times 100 \%=\left(\frac{100-2}{100}\right) \times 100 \%=98 \%$.

The percentage of increasing of mean production was determined by equation (2), i.e:

$$
P_{i}=\left(\frac{M_{P}-M_{C}}{M_{P}}\right) \times 100 \%=\left(\frac{4.41-2.54}{4.41}\right) \times 100 \%=42.40 \%
$$

Mean production of control sample: $M_{P}=\frac{P_{1}+P_{2}+P_{3}+P_{4}+P_{5}}{5}=\frac{2.78+2.47+2.41+2.49+2.65}{5}=2.54$ tons $/ \mathrm{ha}$.

Mean production of mutan: $M_{P}=\frac{P_{1}+P_{2}+P_{3}+P_{4}+P_{5}}{5}=\frac{4.92+4.87+3.96+3.78+4.53}{5}=4.41$ tons $/ \mathrm{ha}$

\section{Results}

\subsection{Observes and Measures}

The important physical and chemical characteristics were observed and measured of local soybean on control

\begin{tabular}{|c|c|c|c|}
\hline No & Description & Control (Initial Variety) & Mutan (Generation Variety) \\
\hline 1 & Grow time & 7 days after planted (dap) & 4 dap \\
\hline 2 & Flowered age & 62 dap & 44 dap \\
\hline 3 & The mean High of plant & $19.25 \mathrm{~cm}$ & $24.65 \mathrm{~cm}$ \\
\hline 4 & Tenacity of germ & not tenacity & Tenacity \\
\hline 5 & Adaptation & $\begin{array}{l}\text { Adaptation to area with high } \\
\text { calcium and salt. }\end{array}$ & Adaptation to area with high calcium and salt, dry condition \\
\hline 6 & Grow percentage & $82 \%$ & $98 \%$ \\
\hline 7 & Protein content & $12.40 \%$ & $13.92 \%$ \\
\hline 8 & Mass per 1,000 seeds & 172.69 grams & 273.77 grams \\
\hline 9 & Maximum production potential & 3.10 tons/ha & 4.92 tons $/$ ha \\
\hline 10 & Mean production & 2.54 tons/ha & 4.41 tons/ha \\
\hline
\end{tabular}
sample and treatment sample (Mutan) included in Table 1, and the production level at the several planting locations of local soybean on control and treatment sample incude in Table 2.

Table 1. The important physical and chemical characteristics were observed, measured, and calculated 
Table 2. Production level at several planting locations of local soybean (Control and treatment sample)

\begin{tabular}{lllll}
\hline & Planting & Control & Mutan \\
\cline { 2 - 5 } No & $\begin{array}{l}\text { Location } \\
\text { (1 hectare) }\end{array}$ & Production level (tons/ha) & Mean production (tons/ha) & Production level (tons/ha) \\
\hline 1 & Oesao $\left(\mathrm{P}_{1}\right)$ & 2.78 & & 4.92 \\
2 & Fukdale $\left(\mathrm{P}_{2}\right)$ & 2.47 & 2.54 & 4.87 \\
3 & Tabenu $\left(\mathrm{P}_{3}\right)$ & 2.41 & & 3.96 \\
4 & Bakunase $\left(\mathrm{P}_{4}\right)$ & 2.39 & & 3.78 \\
5 & Bolok $\left(\mathrm{P}_{5}\right)$ & 2.65 & 4.53 \\
\hline
\end{tabular}

\subsection{Explanation of Figures}

The physical growth of control (initial local soybean from Bajawa Flores Indonesia) and mutan (variety of soybean was obtained from mutation by multigamma radiation treatment) were shown on Figure 2 and Figure 3.

Figure 2, shows two examples of control (initial local soybean variety from Bajawa Flores), which are good to grow at area with high calcium, although fruits of this plants are a little. While, Figure 3, shows two examples of mutan (soybean was obtained from mutation by multigamma radiation treatment), which has meny fruits. On Figure 2 and Figure 3, were show clearly that the fruits of control sample and the fruits of mutan (generation soybean variety) is significantly differenced.

Figure 4, shows one example of control sample (seeds of soybean without treatment), and Figure 5a up to Figure 5e, show 5 examples of mutan (mutan seeds of soybean was obtained from mutation by multigamma radiation (there were 10 varieties). Mutan-1 up to mutan-5 on Figure 5, were obtained by selection. Selection is done appropriate to several important physical and chemical characteristics like as production level, age of plant, mass of seed, seed measuring, high of plant, and flowered age, and other characteristics.

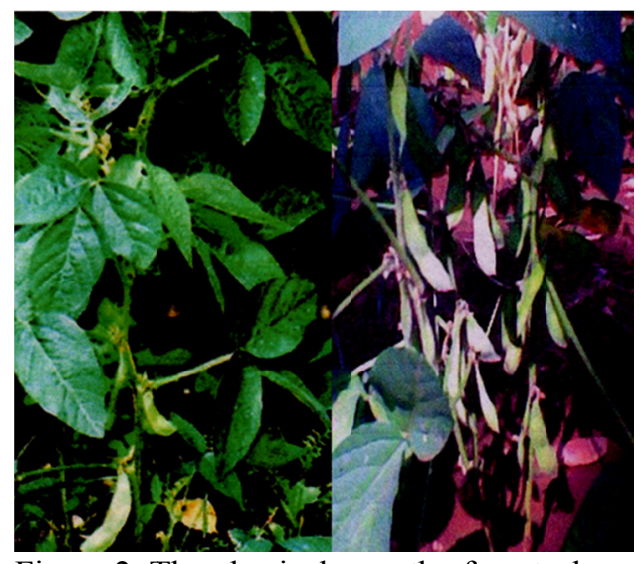

Figure 2. The physical growth of control sample (initial soybean from Bajawa Flores Indonesia)

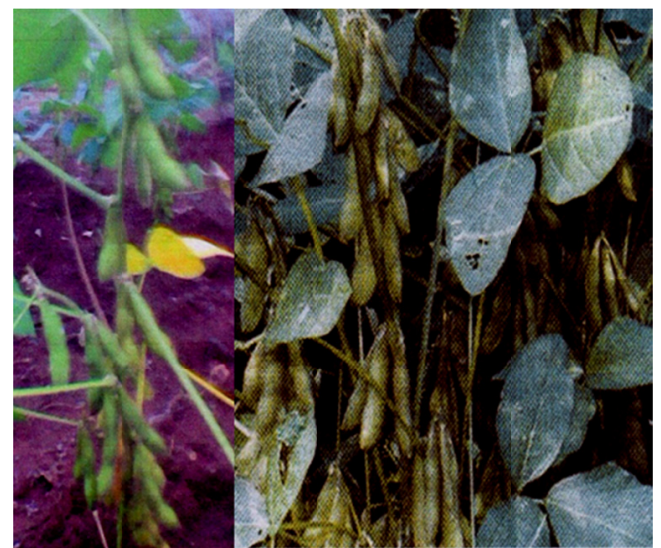

Figure 3. Physical growth mutan (soybean was obtained from mutation by multigamma radiation treatment)

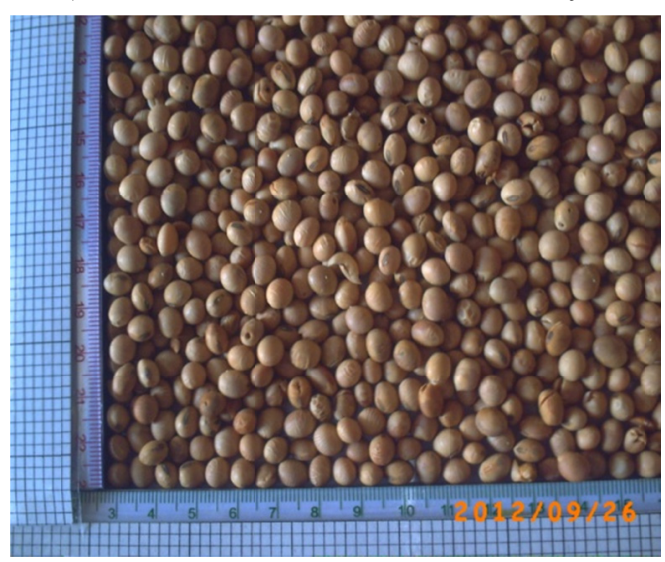

Figure 4. The seeds of control sample (seeds of initial soybean from Bajawa Flores Indonesia) 

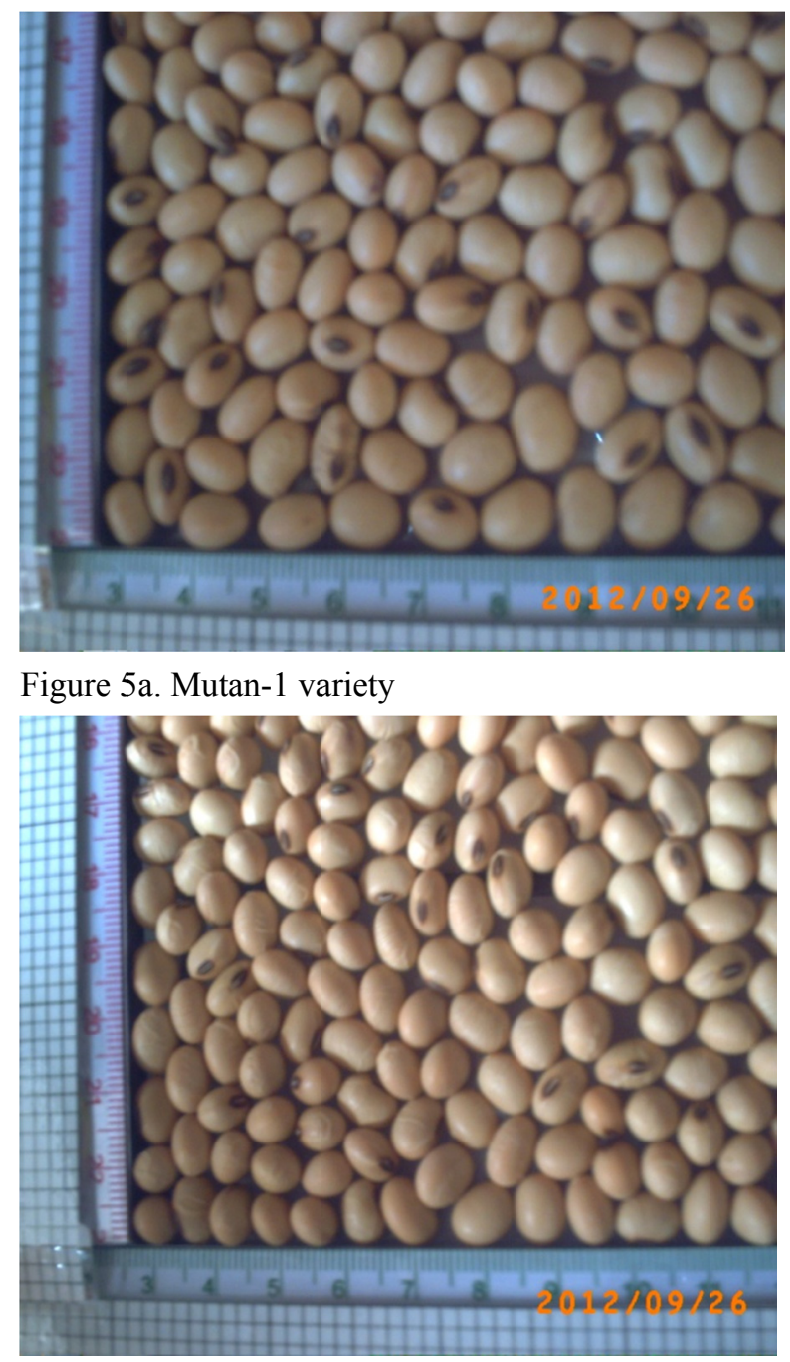

Figure 5c. Mutan -3 variety

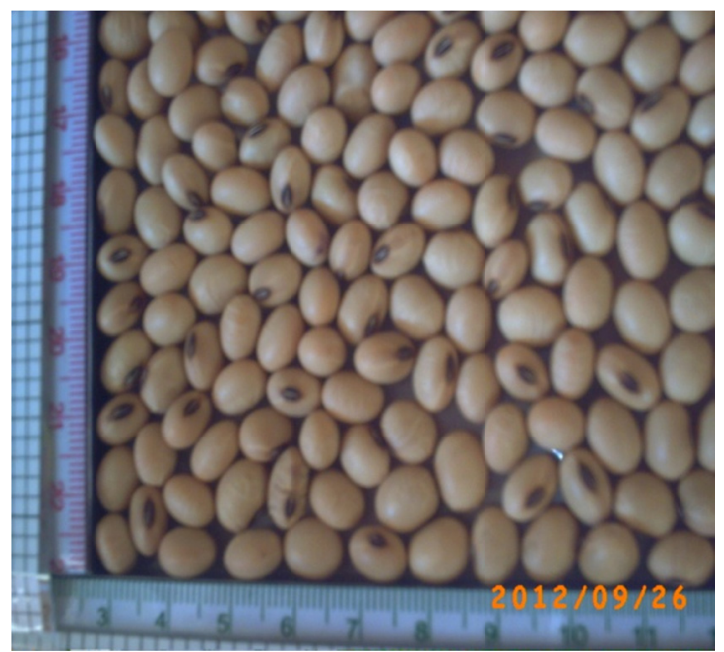

Figure 5b. Mutan-2 variety

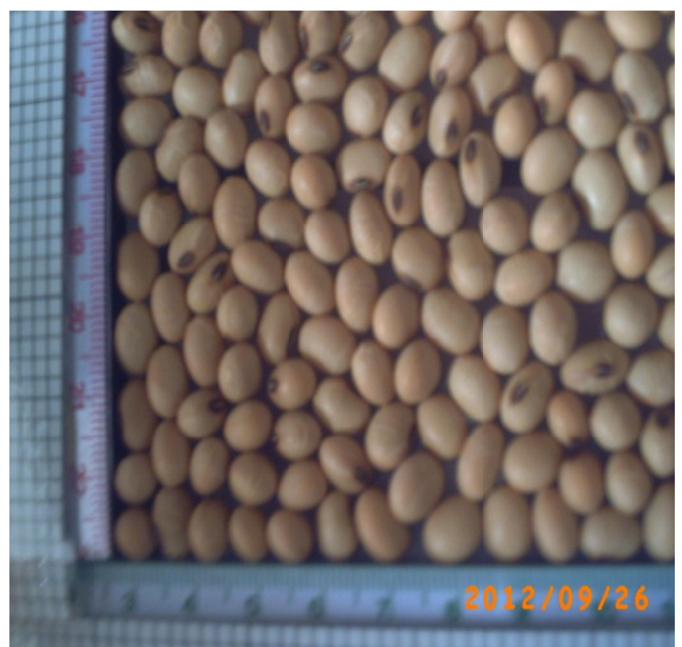

Figure 5d. Mutan-4 variety

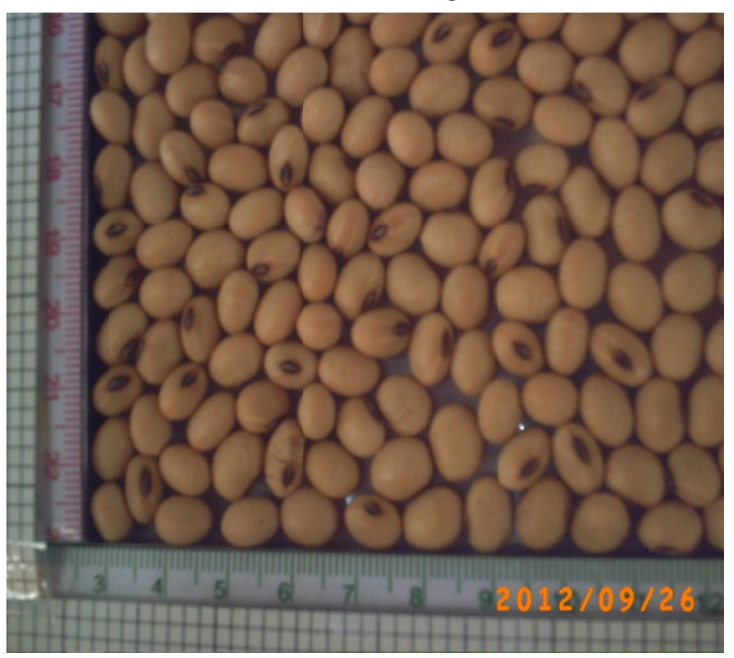

Figure 5e. Mutan -5 variety

Figure 5. Five examples of mutan seeds varieties were obtained from muation by multigamma radiation

The number of seeds was not grown on the control sample and mutan to be included in Table 3 . 
Table 3. Data for evaluating of grow percentage (the number of seeds was not grown on the control sample and mutan).

\begin{tabular}{llll}
\hline Sample & Total number of seeds & Control Sample & Mutan \\
\cline { 3 - 4 } Group & every group & Number of seeds was not grown & Number of seeds was not grown \\
\hline I & 100 & 14 & 3 \\
II & 100 & 17 & 1 \\
III & 100 & 23 & 2 \\
IV & 100 & 19 & 3 \\
V & 100 & 17 & 1 \\
Mean & $\mathbf{1 0 0}$ & $\mathbf{1 8}$ & $\mathbf{2}$ \\
\hline
\end{tabular}

\section{Discussion}

\subsection{Mean Production and Another Characteristics}

Grow time of control sample (initial soybean) is 7 days after planted, and mutan (generation varieties) is 4 days after planted. Flowered age of control sample is 62 days after planted (dap), and mutan vaieties is 44 days after planted (dap). The range of plant high of control sample is $15.32 \mathrm{~cm}$ up to $25.78 \mathrm{~cm}$ (mean is $19.25 \mathrm{~cm}$ ) and mutan varieties is $15.38 \mathrm{~cm}$ up to $32.29 \mathrm{~cm}$ (mean is $24.65 \mathrm{~cm}$ ). The control was adapted to area with high calcium dan salt, and the mutan varieties of local soybean was adapted to area with high calcium, salt, and dry condition. The grow percentage of control sample (initial soybean) is $82 \%$ and the mutan (generation varieties) is $98 \%$. Protein content of control sample is $12.40 \%$ and the mutan is $13.92 \%$. The mean mass of 1,000 seeds of control sample: 172.69 grams, and mutan of soybean: 273.77 grams. The maximum production potential of control sample is 3.10 tons/ha, with mean production 2.54 tons/ha, and generation verieties is 4.92 tons/ha with mean production 4.41 tons/ha. Those data show that physical and chemical characteristics of mutan is superior than control sample (initial soybean). The all characterictics was different clearly. There were ten (10) varieties of primer seed or superior seed were obtained from mutation by multigamma radiation. The improved traits stably inherited in the later generation of those varieties of soybean (10 varietes) will be tested on continuosly research. In other research (Pasangka \& Jaelani, 2009) on corn breeding, we found that the generation of corn has the traits stably inherited up to 7 generations, and after that the production to be more decreased.

Figure 5a-5e, show five examples of mutan seeds. Soybean seeds on: Figure 5a tolerant to germ, dry condition and area is high calcium and high salt, Figure $5 \mathrm{~b}$ tolerant to germ, dry condition, and area is high salt, Figure $5 \mathrm{c}$ tolerant to germ and dry condition. Agricultural location in Kupang Timor Island Indonesia was dominated by soil with high calcium, high salt, and dry condition. So, necessary develop plants that can be adapted to those conditions.

\subsection{Age of Soybean}

On the observation result can be shown that seeds of soybean was irradiated by multigamma radiation grow faster than seeds of soybean without irradiation (Control sample), i.e 4 days after planted, and since the age is 7 days, the growth of sprout is $98 \%$. The plants begin to be flowered since 68 days after planted (dap), and the age of harvest is 94 dap. This case show that production of mutan was obtained faster than initial soybean (control sample).

\subsection{Tolerant to Germ}

Based on observations from first growth until to harvest time was shown clearly that growth of superior local soybean (mutan) tolerant to germ. This case is shown by soft leaf since growth of soybean.

\subsection{The Increase of Mean Production}

Based on data in Table 1 and Table 2, can be suggested any arguments that mutan is more quickly powered, more vertile, mass per 1,000 seeds is higher, grow prcentage is higher, adapted to: germ, dry condition, the main production is higher. The mean production of control sample (initial variety) is 2.54 tons/ha, and mean production of mutan (generation variety) is 4.41 tons/ha. This result shows that mean production of mutan of local soybean from Bajawa Flores Indonesia (was obtained from mutation by multigamma radiation treatment) was increased significantly. The increase of mean production is 42.40 percent. 


\section{Conclusion}

From figures and analysis upon can be proposed that development of local soybean from Bajawa Flores Indonesia by multigamma radiation and carefully selection was obtained primer seeds or superior seeds of soybean with physical and chemical characteristics is superior. The production of superior seeds was obtained from mutation by multigamma radiation treatment is 3.78 tons/ha up to 4.92 tons/ha, mean production 4.41 tons/ha, and the increase of mean production is 42.40 percent.

\section{Acknowledgements}

This research or study was supported by National Strategy Research, Directorate of Reseach and Publc Service, Department of Education and culture of Indonesia Goverment, 2011/2012.

\section{References}

Amaliyah, R. (2009). Application Effect of Agreement on Agriculture to Food Stability of Indonesia. Journal of Global and strategies, 3(2), 20-25.

Arsyad, D. M., \& Syam, dan M. (2004). Development and Cultivation Technique of New Variety of Soybean.Nuclear Technology. BATAN Serpong.

Atman. (2006). Cultivation of Soybean on irrigated field. Journal Science Tambua, V(7), 288-296.

Brenner, D. J., Hall, E. J., \& Sachs, R. K. (2006). Are Bystander Effects Important at Low Radiation Dose? Conference of Radiation effects. Washington, DC.

Carsono, N. (2008). The Benefit of Plant Breeding for Increasing of Agricultural Production in Indonesia, Journal of Nat. Inst of Agro-biologicao Sci, Tsukuba Tokyo. http://dx.doi.org/10.1036/0093-82757(87)90562.1

DP2TP. (2006). Germ, Drying , and Macro-micro elements Problem on Soybean, Research. Journal of Food Plant Flobamora, 1(3), 56-61. Kupang NTT Indonesia.

Gepts, P., \& Hancock, J. (2006). The Future of Plant Breeding. Journal of Biotech Crop Sci., 1(3), 18-23. http://dx.doi.org/11.3148/PS09-001.1

Hall, E. J. (2003). Radiobiology for the Radiologist (5th edn). Philadelphia, USA: Lippincott William \& Wilkins.

Handayani. (2009). Analysis of Morphology and Molecular of Soybean Tolerant to Low Intensity of Light. Journal of Science and Technology Indonesia, 8(1).

Hartati, S. (2000). The Genotive appearance of Tomato as a Result of Mutation on Water stress Conditon and Optimal Condition. Journal Agrosciences, 2(2), 12-16.

Hilman., Y. A., Kasno., dan N. S. (2004). Legumes and Tubers, Contribute to Food Stability in Technology Development. Food Plant Innovation, 95-132. http://dx.doi.org/11.3148/PS08-102.1

Hollaender, A. (2002). Radiation Biology. New York: McGraw-Hill Book Company, Inc.

IAEA. (2006). Preservation of Fruit and Vegetables by Radiation. Journal of Safety Standards Series, 103, 75-93.

IAEA. (2003). Rice Breeding with Induced Mutation. Journal of Tech. Reports Series, 125, 95-102.

IAEA. (2004). Radiation Safety of Gamma and Electron Irradiation Facilities. Journal of Safety Series, 101, 71-98.

Indrawan, S. (2009). The New Superior Variety of Soybean as a Result of Breeding with Radiation Method. Journal Science and Nuclear Technology, 1(6), 12-38. Retrieved from http://sony42.wordpress.com/2009/02/26/

Irwan, A. W. (2006). The Cultivation of Glycine Max L Merill, Agricultural Cultivation, UNPAD Jatinangor.

NNEA. (2005). Doses Limit System, Nuclear Technology Center and Radiometry, National Nuclear Energy Agency. Journal Science and Nuclear Technology, 1(2), 1-6. Bandung Indonesia.

NNEA. (2008). The New Superior Variety of Soybean as a Result of Breeding thrugh Mutation of Radiation, Journal: Atomos Information Media of Science and Nuclear Technology, (1), 1-8. Retrieved from http://www.nnea.go.id/breeding.html

Pasangaka, B. Dan, \& Jaelani, A. K. (2010). The Breeding of Local Corn by Multigamma Radiation Method (Nuclear) in West Timor Nusa Tenggara Timur. Jurnal Teknologi TECHNOSCIENTA, 3(1), 8-21.

Pasangka, B. Dan., \& Jaelani, A. K. (2011). The Development of Local Peanut with Multiculture Based that Tolerant to Abiotic and Biotic Conditions Through Breeding by Multigamma Radiation (Nuclear), First Year. 
Journal of Reearch and Development Bulletin, Indonesia Australia Eastern University Project Alumni Forum, $10(3), 44-61$.

Radiyanto, B., Mochammad, S., \& Nurcahyani, M. (2011). Germ Insect Diversity on Soybean. Journal Entomology Indonesia, 8(2), 8-13. http://dx.doi.org/10.10346/AT09-009.1

Soedjono, S. (2003). The Application of Induce Mutation and Variation in Plant Breeding. Journal Agricultural Science, 1(3), 35-40.

Sunarto (2003). The Toleratnt of Soybeant to Dry Soil. Indonesian Journal of Agronomy, 29(1), 51-56.

United Nations Scientific Committee on the Effects of Atomic Radiation (UNSCEAR). (2005). Continuously Report to the General Assembly. Sources and Effects of Ionizing Radiation. United Nations, New York. 